\title{
STATIC AND DYNAMIC PARAMETERS OF RAILWAY TRACKS RETROFITTED WITH UNDER SLEEPER PADS
}

\author{
C. KRAŚKIEWICZ ${ }^{1}$, A. ZBICIAK ${ }^{2}$, W. OLEKSIEWICZ ${ }^{3}$, W. KARWOWSKI ${ }^{4}$
}

\begin{abstract}
The paper presents results of the laboratory tests made for the prototype resilient under sleeper pads in the Warsaw University of Technology laboratory unit. These pads are dedicated to reduce vibrations transmitted to the vicinity of the railroad and to improve the resistance of the railroad structure. The laboratory testing program was carried out for elastomeric materials (polyurethane and rubber based) due to the PN-EN 16730 standard. The obtained values of the key parameters were used in order to determine the insertion loss vibration level by applying analytical method. The paper presents the influence of selected parameters i.e. static and dynamic moduli on the reduction of vibration and structure-borne sound level.
\end{abstract}

Keywords: under sleeper pads, static bedding modulus, dynamic bedding modulus, dynamic stiffening ratio

\section{INTRODUCTION}

Under sleeper pads (USP) are used in ballasted track system to reduce the dynamic effects transferred from the rolling stock to the ballast. Vibrations are transferred through the rails, fastening system and

\footnotetext{
${ }^{1}$ MSc., Eng., Warsaw University of Technology, Faculty of Civil Engineering, Institute of Roads and Bridges, 16 Armii Ludowej Ave., 00-637 Warsaw, Poland, e-mail: c.kraskiewicz@il.pw.edu.pl

${ }^{2}$ Prof., DSc., PhD., Eng., Warsaw University of Technology, Faculty of Civil Engineering, Institute of Roads and Bridges, 16 Armii Ludowej Ave., 00-637 Warsaw, Poland, e-mail: a.zbiciak@il.pw.edu.pl

${ }^{3}$ PhD., Eng., Warsaw University of Technology, Faculty of Civil Engineering, 16 Armii Ludowej Ave., 00-637 Warsaw, Poland, e-mail: w.oleksiewicz@il.pw.edu.pl

${ }^{4}$ PhD., Eng., Warsaw University of Technology, Faculty of Civil Engineering, 16 Armii Ludowej Ave., 00-637 Warsaw, Poland, e-mail: w.karwowski@il.pw.edu.pl
} 
finally through the rail supporting structure (sleepers or turnout bearers), where the USP can be installed.

USP are produced from elastomeric materials and have two variations due to the used material: pads based on polyurethane (with closed or open pores) and rubber pads (blends of natural rubber and/or synthetic rubber). USP are fixed to the bottom surface of sleepers or turnout bearers. There are two possible cover arrangement of the USP: fully or partially in under rail section (Fig. 1, 2).

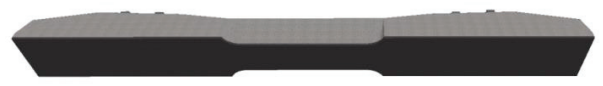

Fig. 1. Under Sleeper Pad - fully covered bottom surface of the sleeper [1]

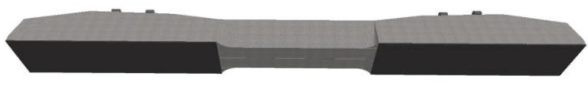

Fig. 2. Under Sleeper Pad - partially covered bottom surface of the sleeper (in the area of the main transmission of vertical pressure) [1].

USP installation takes place during the production process of the sleepers or turnout bearers by placing the pad on the bottom of the formwork before pouring concrete or on finished sleepers/turnout bearers by gluing the pad with fast hardening adhesive (i.e. epoxy glue).

Procedures for testing under sleeper pads are given in standard [2], but it does not specify the required parameter values [3].

\section{STATIC AND DYNAMIC CHARACTERISTIC OF RESILIENT UNDER SLEEPER PADS - LABORATORY TESTS}

In the case of under sleeper pads used in railways, the dedicated European standard and the Polish standard transferring this European one - PN-EN 16730 [2] was introduced just in August 2016. Until then, neither Polish nor European norms existed and there were only the German Standards: DIN 45673-1 [4] and DIN 45673-6 [5]. All the substantial characteristics of resilient pads and procedures for researches due to PN-EN 16730 [2] Standard are presented in study [3]

Static and dynamic bedding moduli determine effectiveness of dumping for the vibrations transmitted to the environment [6]. The range of the static and dynamic bedding moduli values for USP is very wide. These values depend on the material's type and structure, thickness of the pad, the actual load value and - for dynamic modulus - the actual load frequency. 


\subsection{LABORATORY TESTS ASSUMPTIONS}

Under sleeper pads were tested in the research laboratory unit at the Warsaw University of Technology. Two types of USP were tested in accordance with the requirements of the PN-EN 16730 Standard [2]: PUR7 - polyurethane-based pads with a thickness of $7 \mathrm{~mm}$ (Fig. 3), RUB7 and RUB9 rubber-based pads with a thickness of $7 \mathrm{~mm}$ and $9 \mathrm{~mm}$ (Fig. 4).

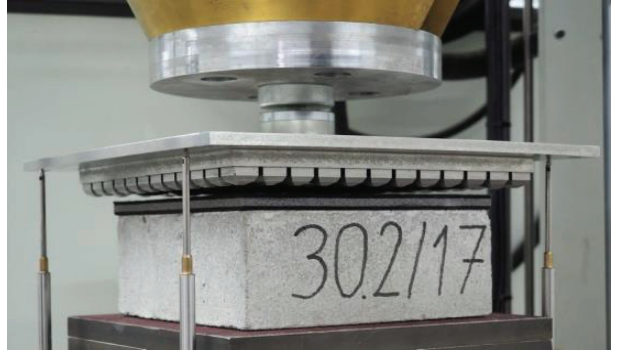

Fig. 3. USP PUR7(30.2) sample tested at the Warsaw University of Technology.

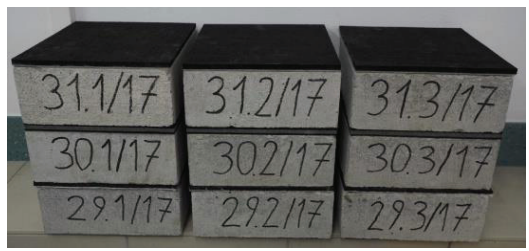

Fig. 5. USP test samples: RUB7(29.1-3), PUR7(30.1-3), RUB9(31.1-3) tested at the Warsaw University of Technology.

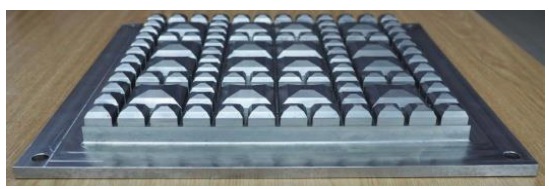

Fig. 6. GBP plate used to tested USP pads in laboratory stand at the Warsaw University of Technology (side view).

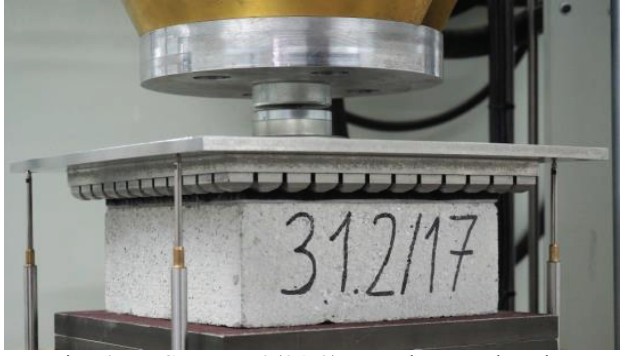

Fig. 4. USP RUB9(31.2) sample tested at the Warsaw University of Technology.

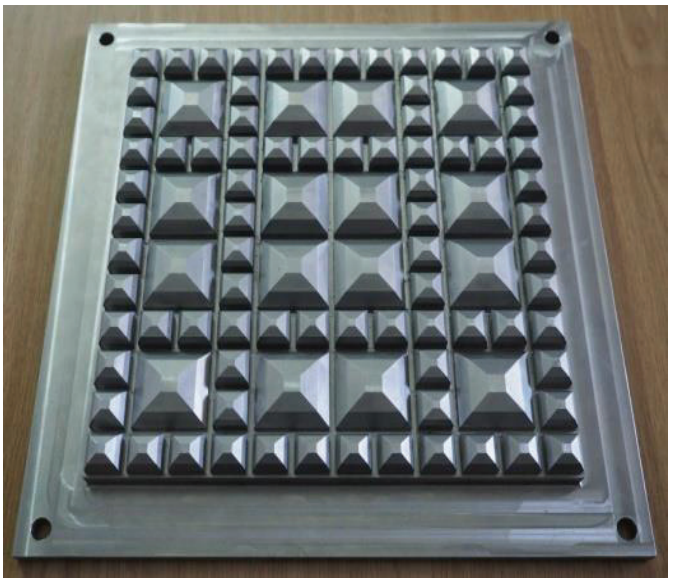

Fig. 7. GBP plate used to tested USP pads in laboratory stand at the Warsaw University of Technology (top view.

Dimensions of the test samples shown on Fig. 5: $250 \mathrm{~mm} \times 250 \mathrm{~mm}$ x thickness of USP on $250 \mathrm{~mm}$ x $250 \mathrm{~mm}$ x $100 \mathrm{~mm}$ concrete block. Test temperature: $23 \pm 5^{\circ} \mathrm{C}$. The load application was realized with geometric ballast plate (GBP), shown on Fig. 6, 7, which transmitted loads to the pads on top 
surface of concrete block. The support of the sample was realized as a non-deformable support with a steel smooth plate covered with a sanding disc (K240 grit on a rigid linen backing cloth).

The sample loading (both static and dynamic) was applied by the INSTRON 8802 hydraulic fatigue testing system. The deflections were measured by four displacement inductive sensors (WA-T type by HBM) together with HBM's Spider8 data acquisition and signal conditioning system and dedicated software - Catman AP.

The tests were dedicated for the concrete sleepers or bearers with under sleeper pads for Track Category no 3 (TC3) according to PN-EN 16730 [2], what means: conventional main line railways with a typical axle load of $225 \mathrm{kN}$, a typical maximum speed of $200 \mathrm{~km} / \mathrm{h}$, a typical rail section of $60 \mathrm{E} 1$ and a typical sleeper or support spacing of $600 \mathrm{~mm}$ or lines with large radius curves, often used for high speed trains and having a typical axle load of $200 \mathrm{kN}$, a typical maximum speed of $320 \mathrm{~km} / \mathrm{h}$, a typical rail section of 60E1, a typical sleeper or support spacing of $600 \mathrm{~mm}$.

\subsection{STATIC BEDDING MODULUS TESTS RESULTS}

Static bedding modulus affects the rail vertical deflection under the load of not moving rolling stock. It also affects the vertical deflection of railway track in floating slab track system. The relationship between static bedding modulus and the applied force is non-linear. The static bedding modulus is determined within different ranges of loads depending on the application purpose of resilient pads (i.eg. Track Category TC3). Static bedding modulus diagrams obtained in conducted tests are shown in Fig. 8 and its numerical values within different evaluation ranges of loads in Tab. 1, 2, 3.

Table 1. Static bedding modulus of USP RUB7

(TC3) according to PN-EN 16730 [2].

\begin{tabular}{|c|c|c|c|c|c|}
\hline \multirow{2}{*}{$\begin{array}{c}\text { Range } \\
\text { of loads }\end{array}$} & \multicolumn{5}{|c|}{ Static bedding modulus $\left[\mathrm{N} / \mathrm{mm}^{3}\right]$} \\
\cline { 2 - 6 }$\left[\mathrm{N} / \mathrm{mm}^{2}\right]$ & $\begin{array}{c}\text { No. } \\
29.1\end{array}$ & $\begin{array}{c}\text { No. } \\
29.2\end{array}$ & $\begin{array}{c}\text { No. } \\
29.3\end{array}$ & $\begin{array}{c}\text { Ave. } \\
\text { val. }\end{array}$ & $\begin{array}{c}\text { Stand. } \\
\text { dev. }\end{array}$ \\
\hline $0.01 \div 0.10$ & 0.101 & 0.098 & 0.096 & $\mathbf{0 . 0 9 8}$ & 0.002 \\
\hline $0.01 \div 0.20$ & 0.140 & 0.137 & 0.135 & $\mathbf{0 . 1 3 8}$ & 0.003 \\
\hline
\end{tabular}

Table 2. Static bedding modulus of USP PUR7

(TC3) according to PN-EN 16730 [2].

\begin{tabular}{|c|c|c|c|c|c|}
\hline \multirow{2}{*}{ Range of loads } & \multicolumn{5}{|c|}{ Static bedding modulus $\left[\mathrm{N} / \mathrm{mm}^{3}\right]$} \\
\cline { 2 - 6 }$\left[\mathrm{N} / \mathrm{mm}^{2}\right]$ & $\begin{array}{c}\text { No. } \\
30.1\end{array}$ & $\begin{array}{c}\text { No. } \\
30.2\end{array}$ & $\begin{array}{c}\text { No. } \\
30.3\end{array}$ & $\begin{array}{c}\text { Ave. } \\
\text { val. }\end{array}$ & $\begin{array}{c}\text { Stand } \\
\text {.dev. }\end{array}$ \\
\hline $0.01 \div 0.10$ & 0.045 & 0.047 & 0.059 & $\mathbf{0 . 0 5 0}$ & 0.007 \\
\hline $0.01 \div 0.20$ & 0.064 & 0.067 & 0.083 & $\mathbf{0 . 0 7 1}$ & 0.010 \\
\hline
\end{tabular}




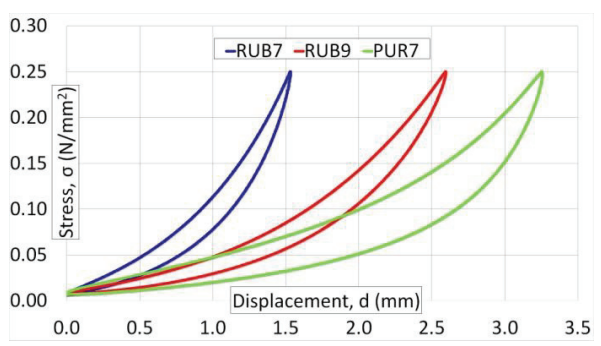

Table 3. Static bedding modulus of USP RUB9

(TC3) according to PN-EN 16730 [2].

Fig. 8. Static bedding modulus of USP

RUB7(29.1)/ RUB9(31.1)/PUR7(30.1)

according to PN-EN 16730 [2]

\subsection{DYNAMIC BEDDING MODULUS TESTS RESULTS}

Dynamic bedding modulus characterizes pad's work under the pressure of moving rolling stock, therefore, it determines limitation of vibrations' transmission. The value of dynamic bedding modulus is related not only to loading force, as in static bedding modulus, but also to load frequencies. Therefore, it should be determined under the standard pressure and frequency ranges.

PN-EN 16730 Standard [2] classifies test procedure into two groups: for dynamic bedding modulus within lower frequencies $C_{d y n}(f)(5,10,20$ and $30 \mathrm{~Hz}$ and for dynamic bedding modulus within higher frequencies $C_{H}(f)(10 \div 160 \mathrm{~Hz})$.

The parameter $C_{d y n}(f)$ can be used to determine the lower-frequency bending deformation of the rail under the influence of the rolling wheel, as a result of the interplay of the bending elasticity of railway track structure.

The parameter $C_{H}(f)$ refers to under sleeper pads and can be used to determine the level of reduction of structure-borne noise. It influences the natural frequency $f_{0}$ of the elastically supported track as an oscillatory system and thus the insertion loss $I L$.

Obtained dynamic bedding modulus $C_{d y n}(f)$ diagrams for tested USP are shown in Fig. 9, 10, 11 and numerical values of dynamic bedding modulus for evaluation range of loads $0.01 \div 0.10 \mathrm{~N} / \mathrm{mm}^{2}$ according to TC3 from PN-EN 16730 [2] in Tab. 4, 5, 6.

Loading sequence diagrams in dynamic bedding modulus $C_{d v n}(f)$ tests for USP RUB7(29.1) are shown in Fig. 12, 13 for evaluation range of loads $0.01 \div 0.10 \quad \mathrm{~N} / \mathrm{mm}^{2}$ (TC3) according to PN-EN $16730[2]$. 


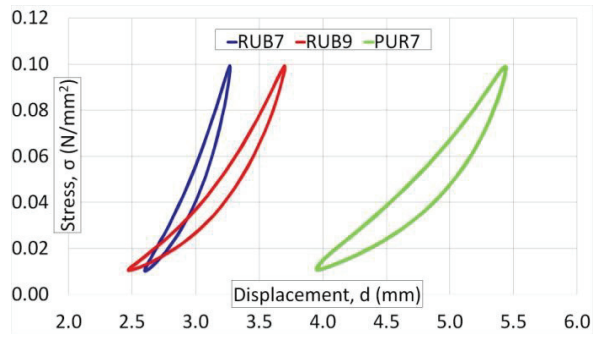

Fig. 9. Dynamic bedding modulus ( $5 \mathrm{~Hz}$ ) of USP

RUB7(29.1)/ RUB9(31.1)/PUR7(30.1) according to PN-EN 16730 [2].

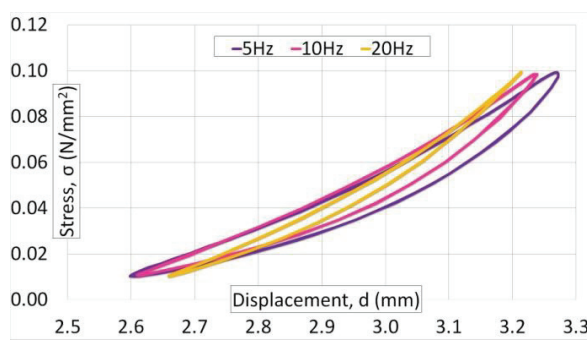

Fig. 11. Dynamic bedding modulus $(5 \mathrm{~Hz}, 10 \mathrm{~Hz}$ and $20 \mathrm{~Hz}$ ) of USP RUB7(29.1) according to PN-EN 16730 [2].

Table 5. Dynamic bedding modulus of USP PUR7 for evaluation range of loads $0.01 \div 0.10$ $\mathrm{N} / \mathrm{mm}^{2}$ (TC3) according to PN-EN 16730

[2].

\begin{tabular}{|c|c|c|c|c|c|}
\hline \multirow{2}{*}{$\begin{array}{c}\text { Frequency } \\
{[\mathrm{Hz}]}\end{array}$} & \multicolumn{5}{|c|}{ Dynamic bedding modulus $\left[\mathrm{N} / \mathrm{mm}^{3}\right]$} \\
\cline { 2 - 6 } & $\begin{array}{c}\text { No. } \\
30.1\end{array}$ & $\begin{array}{c}\text { No. } \\
30.2\end{array}$ & $\begin{array}{c}\text { No. } \\
30.3\end{array}$ & $\begin{array}{c}\text { Ave. } \\
\text { val. }\end{array}$ & $\begin{array}{c}\text { Stand } \\
\text { dev. }\end{array}$ \\
\hline 5 & 0.061 & 0.061 & 0.078 & $\mathbf{0 . 0 6 6}$ & 0.010 \\
\hline 10 & 0.068 & 0.066 & 0.086 & $\mathbf{0 . 0 7 3}$ & 0.011 \\
\hline 20 & 0.081 & 0.082 & 0.103 & $\mathbf{0 . 0 8 9}$ & 0.012 \\
\hline
\end{tabular}



Fig. 10. Dynamic bedding modulus $(20 \mathrm{~Hz})$ of USP RUB7(29.1)/ RUB9(31.1)/PUR7(30.1) according to PN-EN 16730 [2].

Table 4. Dynamic bedding modulus of USP RUB7 for evaluation range of loads $0.01 \div 0.10$ $\mathrm{N} / \mathrm{mm}^{2}$ (TC3) according to PN-EN 16730.

\begin{tabular}{|c|c|c|c|c|c|}
\hline \multirow{2}{*}{$\begin{array}{c}\text { Frequency } \\
{[\mathrm{Hz}]}\end{array}$} & \multicolumn{5}{|c|}{ Dynamic bedding modulus $\left[\mathrm{N} / \mathrm{mm}^{3}\right]$} \\
\cline { 2 - 6 } & $\begin{array}{c}\text { No. } \\
29.1\end{array}$ & $\begin{array}{c}\text { No. } \\
29.2\end{array}$ & $\begin{array}{c}\text { No. } \\
29.3\end{array}$ & $\begin{array}{c}\text { Ave. } \\
\text { val. }\end{array}$ & $\begin{array}{c}\text { Stand. } \\
\text { dev. }\end{array}$ \\
\hline 5 & 0.131 & 0.131 & 0.126 & $\mathbf{0 . 1 2 9}$ & 0.003 \\
\hline 10 & 0.140 & 0.139 & 0.134 & $\mathbf{0 . 1 3 7}$ & 0.003 \\
\hline 20 & 0.161 & 0.158 & 0.153 & $\mathbf{0 . 1 5 7}$ & 0.004 \\
\hline
\end{tabular}

Table 6. Dynamic bedding modulus of USP RUB9 for evaluation range of loads $0.01 \div 0.10$ $\mathrm{N} / \mathrm{mm}^{2}$ (TC3) according to PN-EN 16730 [2].

\begin{tabular}{|c|c|c|c|c|c|}
\hline \multirow{2}{*}{$\begin{array}{c}\text { Frequency } \\
{[\mathrm{Hz}]}\end{array}$} & \multicolumn{5}{|c|}{ Dynamic bedding modulus $\left[\mathrm{N} / \mathrm{mm}^{3}\right]$} \\
\cline { 2 - 6 } & $\begin{array}{c}\text { No. } \\
31.1\end{array}$ & $\begin{array}{c}\text { No. } \\
31.2\end{array}$ & $\begin{array}{c}\text { No. } \\
31.3\end{array}$ & $\begin{array}{c}\text { Ave. } \\
\text { val. }\end{array}$ & $\begin{array}{c}\text { Stand } \\
\text { dev. }\end{array}$ \\
\hline 5 & 0.072 & 0.073 & 0.074 & $\mathbf{0 . 0 7 3}$ & 0.001 \\
\hline 10 & 0.085 & 0.084 & 0.087 & $\mathbf{0 . 0 8 5}$ & 0.001 \\
\hline 20 & 0.097 & 0.096 & 0.099 & $\mathbf{0 . 0 9 7}$ & 0.001 \\
\hline
\end{tabular}




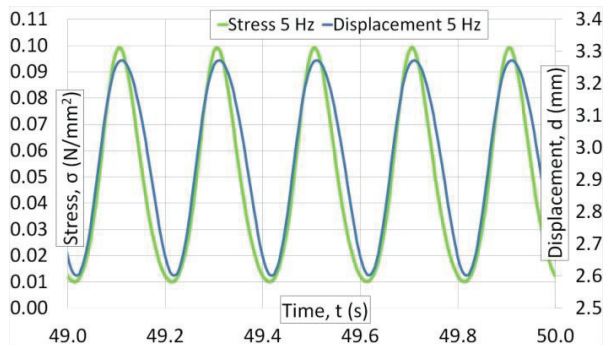

Fig. 12. Dynamic bedding modulus (5 Hz) of USP RUB7(29.1) - loading sequence (TC3) according to PN-EN 16730 [2].

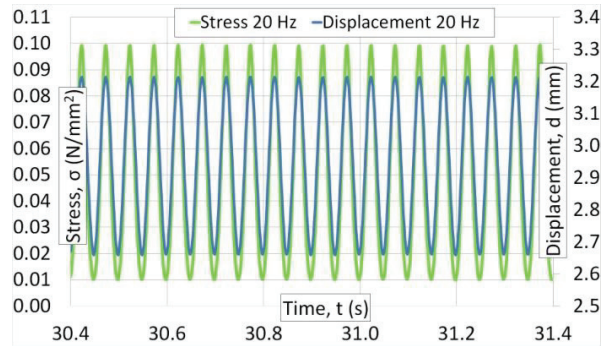

Fig. 13. Dynamic bedding modulus $(20 \mathrm{~Hz})$ of USP

RUB7(29.1) - loading sequence (TC3) according to PN-EN 16730 [2].

\subsection{DYNAMIC STIFFENING RATIO (STIFFENING COEFFICIENT) TESTS RESULTS}

Dynamic stiffening ratio (stiffening coefficient) $\kappa(f)$ is a proportion between dynamic and static bedding modulus. It defines the possibility of achieving effective vibration damping for resilient pads. Because of the known property of elastomeric materials being rate-dependent both bedding modulus as well as stiffness modulus are determined for various frequencies of excitation. The closer to 1 the value of dynamic stiffening ratio is (for $\kappa(f)>1$ ), the better vibration isolation properties has the test piece (e.g. resilient under sleeper pad).

$$
\kappa(f)=\frac{C_{d y n}(f)}{C_{\text {stat }}}
$$

Numerical values of dynamic stiffening ratio $\kappa(f)$ for evaluation range of loads $0.01 \div 0.10 \mathrm{~N} / \mathrm{mm}^{2}$ (TC3) according to PN-EN 16730 [2] are shown in Tab. 7.

Table 7. Dynamic stiffening ratio of USP RUB7/PUR7/RUB9 for evaluation range of loads $0.01 \div 0.10$ $\mathrm{N} / \mathrm{mm}^{2}$ (TC3) according to PN-EN 16730 [2].

\begin{tabular}{|c|c|c|c|}
\hline \multirow{2}{*}{$\begin{array}{c}\text { Frequency } \\
{[\mathrm{Hz}]}\end{array}$} & \multicolumn{3}{|c|}{ Dynamic stiffening ratio [1] } \\
\cline { 2 - 4 } & RUB7 & PUR7 & RUB9 \\
\hline 5 & 1.32 & 1.32 & 1.28 \\
\hline 10 & 1.40 & 1.46 & 1.50 \\
\hline 20 & 1.60 & 1.77 & 1.71 \\
\hline
\end{tabular}




\section{MECHANICAL MODEL OF BALLAST RAILWAY TRACK}

Discrete mechanical model of a ballast railway track is shown in Fig. 14. Such a model being partially analysed in [7] is also presented in Standard [8] for calculation of insertion loss. The state-space formulation of differential equations representing this model is given in [9] applying the algorithm of eigenvalue problem solution described in [10]. In this section there are demonstrated selected dynamic characteristics of the system retrofitted with viscoelastic fractional model of USP (Fig. 14b). Selected features of the system with USP are visualized by comparing to the reference system without USP shown in Fig. 14a.

The reference system is composed of two layers. The following parameters $k_{\mathrm{o}}=220 \mathrm{MN} / \mathrm{m}$ and $d_{\mathrm{o}}=0.265 \mathrm{MNs} / \mathrm{m}$ representing the stiffness and the damping of upper layer of the system (rail, fastening, sleeper and ballast) are assumed. Moreover, additional parameters $k_{u}=1500 \mathrm{MN} / \mathrm{m}$ and $d_{u}=1.2 \mathrm{MNs} / \mathrm{m}$ define lower layer (track-bed). Effective mass of both reference as well as retrofitted (isolated) systems is to be assumed $m_{\text {eff }}=1420 \mathrm{~kg}$.

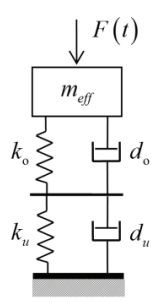

(a)

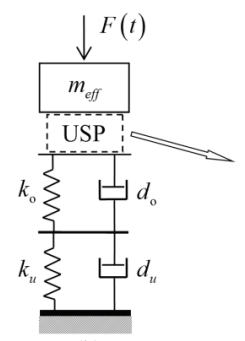

(b)

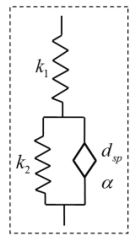

(c)

Fig. 14. Reference model of ballast railway track (a), system with USP (b) and rheological model of USP (c)

In case of isolated system, an additional layer is considered representing under sleeper pad. Rheological viscoelastic model of USP is shown in Fig. 14c. The model is composed of two springs $k_{1}$ and $k_{2}$ and of a fractional element (spring-pot) defined by two parameters $d_{s p}$ and $\alpha$. Constitutive relationships of the spring-pot element, relating the force $f(t)$ and the displacement $u_{s p}(t)$, may be expressed in differential form

$$
f(t):=d_{s p} \mathrm{D}^{\alpha} u_{s p}(t) ; \quad \alpha \in(0,1)
$$

where $\mathrm{D}^{\alpha} \equiv \frac{\mathrm{d}^{\alpha}}{\mathrm{d} t^{\alpha}}$ denotes fractional derivative operator: 
(3a)

$$
\begin{gathered}
\mathrm{D}^{\alpha} u_{s p}(t):=\frac{u_{s p}(0)}{\Gamma(1-\alpha) t^{\alpha}}+\frac{1}{\Gamma(1-\alpha)} \int_{0}^{t} \frac{\dot{u}_{s p}(\tau)}{(t-\tau)^{\alpha}} \mathrm{d} \tau \\
\Gamma(1-\alpha):=\int_{0}^{\infty} t^{-\alpha} e^{-t} \mathrm{~d} t
\end{gathered}
$$

Taking $\alpha=1$ in Eqn. (2) leads to classical dashpot model, while assuming $\alpha=0$ gives simple spring element. Using rheological models containing dashpot elements allows better approximation of experimental results for various engineering materials (see [11]).

Based on laboratory results presented in previous section, rheological parameters of three types of USP can be evaluated. The results of a curve fitting procedure are presented in Table 8 and depicted in Fig. 15. The curve fitting procedure is based on evaluation of dynamic stiffness moduli being the absolute value of the complex stiffness $k_{U S P}^{*}$.

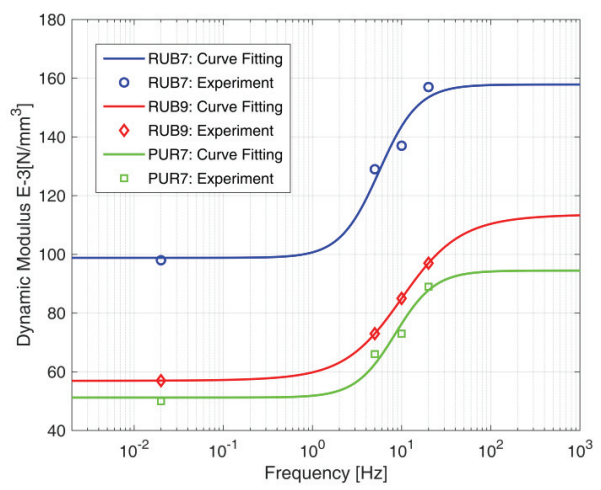

Table 8. Curve fitting results of rheological models

\begin{tabular}{|c|c|c|c|c|}
\multicolumn{7}{|c|}{ of USPs. } \\
\begin{tabular}{|c|c|c|c|}
$k_{1}$ \\
USP \\
{$[\mathrm{MN} / \mathrm{m}]$}
\end{tabular} & $\begin{array}{c}k_{2} \\
{[\mathrm{MN} / \mathrm{m}]}\end{array}$ & $\begin{array}{c}d_{s p} \\
{\left[\mathrm{MNs}^{\alpha} / \mathrm{m}\right]}\end{array}$ & $\alpha[1]$ \\
\hline RUB7 & 15.786 & 26.423 & 1.087 & 0.998 \\
\hline RUB9 & 11.368 & 11.403 & 0.621 & 0.836 \\
\hline PUR7 & 9.448 & 11.189 & 0.334 & 0.997 \\
\hline
\end{tabular}

Fig. 15. Curve fitting results for three analysed USP models.

It should be emphasized that the values of bedding moduli evaluated based on the curve fitting procedure (Fig. 15) are divided by the area of the sample $(250 \times 250 \mathrm{~mm})$ in order to obtain stiffness moduli shown in Table 8.

The complex stiffness of the USP model $k_{U S P}^{*}$ and of entire isolated system $k_{v i b}^{*}$ can be defined as follows [12]

$$
k_{U S P}^{*}(i \omega)=\left[\frac{1}{k_{1}}+\frac{1}{k_{2}+d_{s p}(i \omega)^{\alpha}}\right]^{-1}
$$




$$
k_{v i b}^{*}(i \omega)=\left[\frac{1}{k_{r e f}^{*}(i \omega)}+\frac{1}{k_{U S P}^{*}(i \omega)}\right]^{-1}
$$

Moreover, it is possible to define complex transfer functions for both reference system $H_{r e f}^{*}(i \omega)$ as well as isolated system $H_{v i b}^{*}(i \omega)$ :

$$
\begin{gathered}
H_{r e f}^{*}(i \omega)=\frac{k_{r e f}^{*}(i \omega)}{k_{r e f}^{*}(i \omega)-m_{e f f} \omega^{2}} \\
H_{v i b}^{*}(i \omega)=\frac{k_{v i b}^{*}(i \omega)}{k_{v i b}^{*}(i \omega)-m_{e f f} \omega^{2}}
\end{gathered}
$$

Absolute value of the complex transfer function can be interpreted as transmissibility of harmonically excited system.

The above definitions can be used to establish so called insertion loss parameter

$$
I L(\omega)=20 \cdot \log _{10}\left|\frac{H_{r e f}^{*}(i \omega)}{H_{v i b}^{*}(i \omega)}\right| \mathrm{dB}
$$
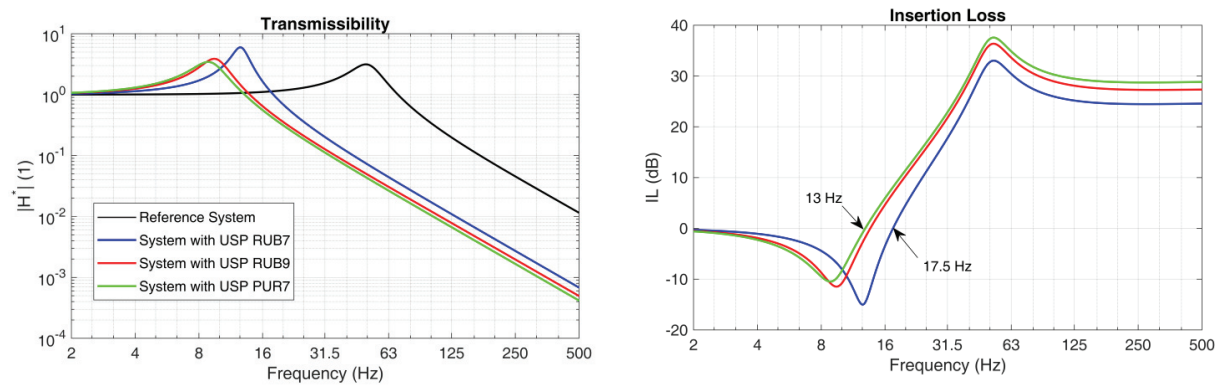

Fig. 16. Transmissibility and Insertion Loss: reference system and systems with three analysed USP models.

The results of calculation for both reference system as well as vibro-isolated systems retrofitted with USP are visualized in Fig. 16. Horizontal axis used in Fig. 16 represents centre frequencies of 1/3 octave bands. The plots depicted in Fig. 16 indicate a region of vibration-isolation effectiveness where $I L>0 \mathrm{~dB}$. In case of PUR7 and RUB9, the verge of vibration-isolation effectiveness equals $13 \mathrm{~Hz}$ while for RUB7 it starts from $17.5 \mathrm{~Hz}$.

Such diagrams are presented in many papers $[13,14,15,16]$ for various mechanical models representing railway track systems with vibroacoustic isolators. 


\section{Conclusions}

The static bedding modulus, dynamic bedding modulus and dynamic stiffening ratio were investigated at the Warsaw University of Technology laboratory unit due to PN-EN 16730 Standard. The testing stand with dedicated instrumentation was designed and constructed. The internal detailed procedure for testing was prepared and verified. The obtained results were used in analysis to determine the insertion loss vibration level. The influence of selected parameters (i.e. static and dynamic bedding moduli) on the reduction of vibration and structure-borne sound level (i.e. the value of insertion loss parameters) was confirmed.

In case of USP with static bedding modulus approx. $0.050 \mathrm{~N} / \mathrm{mm}^{3}$ and dynamic stiffening ratio $\leq 2.0$ (PUR7 and RUB9), the verge of vibration-isolation effectiveness equals approx. $13 \mathrm{~Hz}$ while for USP possessing static bedding modulus approx. $0.100 \mathrm{~N} / \mathrm{mm}^{3}$ and dynamic stiffening ratio $\leq 2.0$ (RUB7) it starts from approx. $17.5 \mathrm{~Hz}$. The research used samples of USP pads, tested by force method. The USP samples turned out to be very soft, hence a significant region of vibration-isolation effectiveness (IL>0) can be observed (see Fig. 16).

The subsequent work also takes into account the results of USP testing by using displacement method (the procedure involves static preloading).

\section{REFERENCES}

1. C. Kraśkiewicz, "Współczesne budownictwo w badaniach młodych naukowców", Politechnika Gdańska, Wydział Inżynierii Lądowej i Srodowiska, pp 126-140, 2017

2. PN-EN 16730:2016-08 "Railway applications - track - concrete sleepers and bearers with under sleeper pads"

3. C. Kraśkiewicz, W. Oleksiewicz, A. Zbiciak, „Podkładki podpodkładowe w podsypkowej konstrukcji nawierzchni dróg szynowych - techniczne i formalne aspekty stosowania”, Archives of Institute of Civil Engineering 25, Politechnika Poznańska, pp 221-243, 2017

4. DIN 45673-1:2010-08 "Mechanical vibration. Resilient elements used in railway tracks. Part 1: Terms and definitions, classification, test procedures"

5. DIN 45673-6:2010-08 "Mechanical vibration. Resilient elements used in railway tracks. Part 6: Laboratory test procedures for under-sleeper pads on concrete sleepers"

6. C. Kraśkiewicz, C. Lipko, M. Płudowska, W. Oleksiewicz, A. Zbiciak, „Static and dynamic characteristics of resilient mats for vibration isolation of railway tracks", Procedia Engineering 153, pp 317-324, 2016

7. A. Zbiciak, C. Kraśkiewicz, C. Lipko, W. Oleksiewicz, „Viscoelastic dynamic models of resilient elements used in railway tracks", IPICSE-2016, MATEC Web of Conferences 86, 01015, 2016

8. DIN 45673-4:2008-07 "Mechanical vibration. Resilient elements used in railway tracks. Part 4: Analytical evaluation of insertion loss of mounted track systems"

9. A. Zbiciak, C. Kraśkiewicz, W. Oleksiewicz, M. Płudowska-Zagrajek, C. Lipko "Mechanical modelling and application of vibroacoustic isolators in railway tracks", , XXVI R-S-P Seminar 2017, Theoretical Foundation of Civil Engineering, MATEC Web of Conferences 117, 00090, 2017

10. V. G. S. Simionatto, H. H. Miyasato, F. Melo, M. Dias, "Singular Mass Matrices and Half Degrees of Freedom: A General Method for System Reduction”, Proceedings $21^{\text {st }}$ Int. Congr. Mech. Engin. (2011)

11. W. Grzesikiewicz, A. Wakulicz, A. Zbiciak, ,Non-linear problems of fractional calculus in modeling of mechanical systems", IJMS 70, pp 90-98, 2013 
12. W. Grzesikiewicz, J. Osiecki, J. Piotrowski, "Podstawy dynamiki pojazdów szynowych", Wydawnictwa Politechniki Warszawskiej, 1974

13. R. G. Wettschureck, U. J. Kurze, „Einfügungsdämm-Maß von Unterschottermatten“, ACUSTICA 58, pp. 177-182, 1985

14. R. G. Wettschureck, „Unterschottermatten auf einer Eisenbahnbrücke in Stahlbeton-Verbundbauweise“, DAGA 87, Aachen, pp. 217-220, 1987

15. R. G. Wettschureck, M. Heim, S. Mühlbachler, "Reduction of structure-borne noise emissions from above-ground railway lines by means of ballast mats", Proceedings Inter-noise 97, Budapest, pp. 577-580, 1997

16. J. Sołkowski, "Efektywność wibroizolacji nawierzchni kolejowej w ujęciu analitycznym", Proceeding, Research and Technical Papers of Polish Association for Transportation Engineers in Cracow 2(106), pp 159-175, 2015

\section{LIST OF FIGURES AND TABLES:}

Fig. 1. Under Sleeper Pad - fully covered bottom surface of the sleeper [1]

Rys. 1. Podkładka podpodkładowa (USP) - całościowe pokrycie powierzchni dolnej podkładu [1]

Fig. 2. Under Sleeper Pad - partially covered bottom surface of the sleeper (in the area of the main transmission of vertical pressure) [1]

Rys. 2. Podkładka podpodkładowa (USP) - częściowe pokrycie powierzchni dolnej podkładu (w strefie głównego przekazywania nacisków pionowych) [1]

Fig. 3. USP PUR7(30.2) sample tested at the Warsaw University of Technology

Rys. 3. Próbka podkładki USP PUR7(30.2) badanej na Politechnice Warszawskiej

Fig. 4. USP RUB9(31.2) sample tested at the Warsaw University of Technology

Rys. 4. Próbka podkładki USP RUB9(31.2) badanej na Politechnice Warszawskiej

Fig. 5. USP test samples: RUB7(29.1-3), PUR7(30.1-3), RUB9(31.1-3) tested at the Warsaw University of Technology

Rys. 5. Próbki podkładek USP: RUB7(29.1-3), PUR7(30.1-3), RUB9(31.1-3) badanych na Politechnice Warszawskiej

Fig. 6. GBP plate used to tested USP pads in laboratory stand at the Warsaw University of Technology (side view)

Rys. 6. Geometryczna płyta dociskowa (GBP) użyta do badania podkładek USP na stanowisku laboratoryjnym na Politechnice Warszawskiej (widok z boku)

Fig. 7. GBP plate used to tested USP pads in laboratory stand at the Warsaw University of Technology (top view)

Rys. 7. Geometryczna płyta dociskowa (GBP) użyta do badania podkładek USP na stanowisku laboratoryjnym na Politechnice Warszawskiej (widok z góry)

Fig. 8. Static bedding modulus of USP RUB7(29.1)/RUB9(31.1)/PUR7(30.1) according to PN-EN 16730 [2]

Rys. 8. Statyczny moduł sztywności podkładki USP RUB7(29.1)/RUB9(31.1)/PUR7(30.1) zgodnie z PN-EN $16730[2]$

Fig. 9. Dynamic bedding modulus (5 Hz) of USP RUB7(29.1)/RUB9(31.1)/PUR7(30.1) according to PNEN 16730 [2]

Rys. 9. Dynamiczny moduł sztywności (5 Hz) podkładki USP RUB7(29.1)/RUB9(31.1)/PUR7(30.1) zgodnie z PN-EN 16730 [2] 
Fig. 10. Dynamic bedding modulus (20 Hz) of USP RUB7(29.1)/RUB9(31.1)/PUR7(30.1) according to PNEN 16730 [2]

Rys. 10. Dynamiczny moduł sztywności $(20 \mathrm{~Hz})$ podkładki USP RUB7(29.1)/RUB9(31.1)/PUR7(30.1) zgodnie z PN-EN 16730 [2]

Fig. 11. Dynamic bedding modulus ( $5 \mathrm{~Hz}, 10 \mathrm{~Hz}$ and $20 \mathrm{~Hz}$ ) of USP RUB7(29.1) according to PN-EN 16730 [2]

Rys. 11. Dynamiczny moduł sztywności (5 Hz, $10 \mathrm{~Hz}$ i $20 \mathrm{~Hz}$ ) podkładki USP RUB7(29.1) zgodnie z PN-EN 16730 [2]

Fig. 12. Dynamic bedding modulus (5 Hz) of USP RUB7(29.1) - loading sequence (TC3) according to PNEN 16730 [2]

Rys. 12. Dynamiczny moduł sztywności (5 Hz) podkładki USP RUB7(29.1) - sekwencja obciążeń dla kategorii toru TC3 zgodnie z PN-EN 16730 [2]

Fig. 13. Dynamic bedding modulus (20 Hz) of USP RUB7(29.1) - loading sequence (TC3) according to PNEN 16730 [2]

Rys. 13. Dynamiczny moduł sztywności $(20 \mathrm{~Hz})$ podkładki USP RUB7(29.1) - sekwencja obciążeń dla kategorii toru TC3 zgodnie z PN-EN 16730 [2]

Fig. 14. Reference model of ballast railway track (a), system with USP (b) and rheological model of USP (c).

Rys. 14. Układ referencyjny podsypkowej konstrukcji nawierzchni kolejowej (a), układ podsypkowej konstrukcji nawierzchni kolejowej z podkładką USP (b) oraz model reologiczny podkładki USP

Fig. 15. Curve fitting results for three analysed USP models

Rys. 15. Wyniki dopasowania krzywych wartości modułu sztywności w funkcji częstotliwości dla trzech analizowanych modeli podkładek USP

Fig. 16. Transmissibility and Insertion Loss: reference system and systems with three analysed USP models

Rys. 16. Funkcja przenoszenia drgań i współczynnik tłumienia dodanego: układ referencyjny oraz układ z trzema analizowanymi podkładkami USP

Table 1. Static bedding modulus of USP RUB7 (TC3) according to PN-EN 16730 [2]

Tablica 1. Statyczny moduł sztywności podkładki USP RUB7 (TC3) zgodnie z PN-EN 16730 [2]

Table 2. Static bedding modulus of USP PUR7 (TC3) according to PN-EN 16730 [2]

Tablica 2. Statyczny moduł sztywności podkładki USP PUR7 (TC3) zgodnie z PN-EN 16730 [2]

Table 3. Static bedding modulus of USP RUB9 (TC3) according to PN-EN 16730 [2]

Tablica 3. Statyczny moduł sztywności podkładki USP RUB9 (TC3) zgodnie z PN-EN 16730 [2]

Table 4. Dynamic bedding modulus of USP RUB7 for evaluation range of loads $0.01 \div 0.10 \mathrm{~N} / \mathrm{mm}^{2}$ (TC3) according to PN-EN 16730 [2]

Tablica 4. Dynamiczny moduł sztywności podkładki USP RUB7 dla zakresu obciążeń ocenianych $0.01 \div 0.10$ N/mm² (TC3) zgodnie z PN-EN 16730 [2]

Table 5. Dynamic bedding modulus of USP PUR7 for evaluation range of loads $0.01 \div 0.10 \mathrm{~N} / \mathrm{mm}^{2}$ (TC3) according to PN-EN 16730 [2]

Tablica 5. Dynamiczny moduł sztywności podkładki USP PUR7 dla zakresu obciążeń ocenianych $0.01 \div 0.10$ N/mm² (TC3) zgodnie z PN-EN 16730 [2] 
Table 6. Dynamic bedding modulus of USP RUB9 for evaluation range of loads $0.01 \div 0.10 \mathrm{~N} / \mathrm{mm}^{2}$ (TC3) according to PN-EN 16730 [2]

Tablica 6. Dynamiczny moduł sztywności podkładki USP RUB9 dla zakresu obciążeń ocenianych $0.01 \div 0.10$ N/mm² (TC3) zgodnie z PN-EN 16730 [2]

Table 7. Dynamic stiffening ratio of USP RUB7/PUR7/RUB9 for evaluation range of loads $0.01 \div 0.10$ $\mathrm{N} / \mathrm{mm}^{2}$ (TC3) according to PN-EN 16730 [2]

Tablica 7. Współczynnik przesztywnienia dynamicznego podkładek USP RUB7/PUR7/RUB9 dla zakresu obciążeń ocenianych $0.01 \div 0.10 \mathrm{~N} / \mathrm{mm}^{2}$ (TC3) zgodnie z PN-EN 16730 [2]

Table 8. Curve fitting results of rheological models of USPs

Tablica 8. Wartości liczbowe elementów składowych modeli reologicznych dopasowujacych krzywe wartości modułu sztywności w funkcji częstotliwości dla trzech analizowanych podkładek USP 


\section{STATYCZNE I DYNAMICZNE PARAMETRY TORU KOLEJOWEGO Z PODKLADKAMI PODPODKLADOWYMI}

Słowa kluczowe: podkładki podpodkładowe, statyczny moduł sztywności, dynamiczny moduł sztywności, współczynnik

przesztywnienia dynamicznego

\section{STRESZCZENIE:}

Artykuł prezentuje wyniki badań wykonanych na prototypowych podkładkach podpodkładowych (USP - skrót od ang. Under Sleeper Pads) na stanowisku laboratoryjnym na Wydziale Inżynierii Lądowej Politechniki Warszawskiej. Podkładki USP stosowane są $\mathrm{w}$ torach $\mathrm{i}$ w rozjazdach o podsypkowej konstrukcji nawierzchni szynowej w celu ograniczenia niekorzystnych oddziaływań dynamicznych od ruchu pojazdów szynowych na otoczenie trasy - przede wszystkim ograniczenia poziomu wibracji. Elementy te zwiększają także trwałość nawierzchni szynowej poprzez zwiększenie powierzchni sprężystego przenoszenia dynamicznych obciążeń na styku podsypki tłuczniowej i podpory szynowej, co przeciwdziała rozkruszaniu ziaren podsypki i tworzeniu się rys i mechanicznych uszkodzeń (wgłębień) na spodzie podkładów.

Program badań charakterystyk sprężystych podkładek USP, który spełnia wymagania normy PN-EN 16730, dotyczył trzech odmian elastomerowych podkładek USP (na bazie poliuretanu - PUR7 i gumy - RUB7 i RUB9 o zróżnicowanej sztywności).

Dla odmian tych podkładek USP przeprowadzono analizę porównawczą zmian wartości dynamicznego modułu ich sztywności w funkcji częstotliwości obciążenia oraz przy zastosowaniu modelu podsypkowej nawierzchni szynowej prognozę ograniczenia poziomu wibracji, charakteryzowanego wartością tzw. współczynnika tłumienia dodanego (ang. Insertion Loss).

Wyznaczone w badaniach laboratoryjnych najistotniejsze parametry statyczne i dynamiczne posłużyły do wyznaczenia wartości parametru tzw. thumienia dodanego z zastosowaniem modelu analitycznego konstrukcji nawierzchni kolejowej. Artykuł wykazał istotny wpływ wybranych parametrów - statycznego i dynamicznego modułu sztywności oraz współczynnika przesztywnienia dynamicznego podkładek USP na poziom redukcji wibracji od ruchu kolejowego. W przypadku podkładek USP o wartości statycznego modułu sztywności ok. 0,050 N/mm $\mathrm{mm}^{3} \mathrm{i}$ współczynnika przesztywnienia dynamicznego $\leq 2,0$ (PUR7 and RUB9), zakres efektywnego tłumienia wibracji zaczyna się od częstotliwości wymuszenia ok. $13 \mathrm{~Hz}$ podczas gdy dla USP o wartości statycznego modułu sztywności ok. $0,100 \mathrm{~N} / \mathrm{mm}^{3}$ i współczynnika przesztywnienia dynamicznego $\leq 2,0$ (RUB7) zakres efektywnego thumienia wibracji zaczyna się od częstotliwości ok. $17,5 \mathrm{~Hz}$. 